\title{
RECENT DEVELOPMENTS IN INDIANA EVIDENCE LAW: OCTOBER 1, 2013 TO SEPTEMBER 30, 2014
}

\author{
YVONNE M. DUTTON*
}

\section{INTRODUCTION}

The Indiana Rules of Evidence ("Rules") were codified in 1994. ${ }^{1}$ Since that time, the Rules have been applied, explained, and interpreted through court decisions. They have also been refined through statutory revisions. This Article describes the developments in Indiana evidence law during the survey period of October 1, 2013, through September 30, 2014. This Article is not intended to provide an exhaustive discussion of every case applying an Indiana Rule of Evidence. Nor does the Article discuss every Indiana Rule of Evidence. Rather, it summarizes the more important developments in this area of practice. The discussion topics follow the order of the Rules.

\section{General Provisions (RULES 101-106)}

Rule 101(a) states that the Rules apply to all court proceedings in Indiana unless "otherwise required by the Constitution of the United States or Indiana, by the provisions of this rule, or by other rules promulgated by the Indiana Supreme Court." 2 Common law and statutory law apply to issues that are not covered specifically in the Rules. ${ }^{3}$ United States District Court Judge Robert L. Miller, Jr. of the Northern District of Indiana has explained this as follows:

[I]n resolving an evidentiary issue, a court must consult the evidence rules first; if they provide an answer, all other sources, whether statutory or case law, are to be disregarded. In deciding whether the evidence rules provide an answer, the rules are to be construed in accordance with the principles articulated in Rule 102. If the evidence rules provide no answer, the court must turn to common law and statutory sources. ${ }^{4}$

As to the referenced Rule 102, it states that the Rules "should be construed so as to administer every proceeding fairly, eliminate unjustifiable expense and delay, and promote the development of evidence law, to the end of ascertaining the truth and securing a just determination."

Rule 103 provides that a party must preserve any claim of evidentiary error

* Associate Professor of Law, Indiana University Robert H. McKinney School of Law. B.A., magna cum laude, Columbia University; J.D., Columbia University School of Law; Ph.D., University of Colorado at Boulder.

1. Romo v. State, 941 N.E.2d 504, 506 (Ind. 2011).

2. IND. R. EVID. 101(a).

3. IND. R. EVID. 101(b).

4. 13B Robert L. Miller, JR., Indiana Practice Series: Courtroom Handbook on INDIANA EVIDENCE $§ 102 \mathrm{cmt} .1$ (2014 ed.).

5. $I d$. 
in order for it to serve as a basis for an appeal from the outcome at trial. ${ }^{6}$ As to a claim of error in admitting certain evidence, the party must timely object or move to strike and also state the specific basis for the objection. ${ }^{7}$ As to a claim that evidence was erroneously excluded, the party must preserve the claim by making an offer of proof at trial. ${ }^{8}$ Further, to succeed on appeal based on an asserted evidentiary error at trial, the party must show that the error affected a "substantial right of the party." In Barnhart v. State, the Indiana Court of Appeals stated that it considers errors harmless, as opposed to affecting a substantial right, where the "probable impact on the jury, in light of all of the evidence in the case, is sufficiently minor." appellate court concluded that because other evidence in the case connected the defendant to the crime, the trial court's decision to exclude evidence proffered by the defendant was harmless error. ${ }^{11}$

\title{
II. Judicial Notice (RUle 201)
}

Rule 201 sets out the types of matters of which a court may take judicial notice. $^{12}$ Among other things, under Rule 201(b)(5), a court may take judicial notice of "records of a court of this state."13 In Withers $v$. State, the Indiana Court of Appeals was called upon to interpret that provision when reviewing the defendant's argument that the trial court had "committed fundamental error in taking judicial notice of attendance reports in her Drug Court file." ${ }^{\prime 4}$ The court of appeals rejected Withers' argument of fundamental error, noting instead that the attendance reports in Withers' file were noticeable under Rule 201(b)(5) since they were "records of the Drug Court, prepared under its supervision and as part of its treatment program for Withers." ${ }^{15}$ The court further explained that judicially noticing the existence of the attendance records did not mean that the facts in the records had to be taken as conclusive. ${ }^{16}$ Rather, even though the records were judicially noticed, the parties remained free to contest the facts within them. ${ }^{17}$

\author{
6. IND. R. EVID. 103(a). \\ 7. $I d$. \\ 8. $I d$. \\ 9. Id. \\ 10. Barnhart v. State, 15 N.E.3d 138, 143 (Ind. Ct. App. 2014). \\ 11. Id. at 145 . \\ 12. IND. R. EVID. 201. \\ 13. IND. R. EVID. 201(b)(5). \\ 14. Withers v. State, 15 N.E.3d 660, 662 (Ind. Ct. App. 2014). \\ 15. Id. at 664 . \\ 16. Id. \\ 17. Id. at 664-65.
}




\section{RELEVANCY AND ITS LIMITS (RULES 401-413)}

\section{A. Probative Value Versus Unfair Prejudice (Rule 403)}

Rule 401 considers evidence "relevant" if "it has any tendency to make a fact more or less probable than it would be without the evidence [and if] . . the fact is of consequence in determining the action." 18 Although Rule 402 bars the introduction of irrelevant evidence, ${ }^{19}$ courts need not admit all relevant evidence. $^{20}$ Courts can refuse to admit relevant evidence if admission is prohibited by the state or federal constitution, a statute, other provisions within the Indiana Rules of Evidence, or other court rules. ${ }^{21}$

Moreover, Rule 403 establishes some specific limits on the admission of relevant evidence. ${ }^{22}$ Under that rule, a court may exclude relevant evidence if its probative value is substantially outweighed by any of the following: potential confusion of issues, unfair prejudice, undue delay, or accumulation of evidence. ${ }^{23}$ The Indiana Court of Appeals applied and elaborated upon Rule 403 in Remy v. State. ${ }^{24}$ There, defendant Remy challenged his conviction for child molestation, among other things, arguing that the trial court abused its discretion by permitting certain pornographic materials to be admitted into evidence during his trial. ${ }^{25}$ The defendant argued that the pornographic materials were improper character evidence not admissible under Rule 404(b) ${ }^{26}$ Rule 404(b) permits the introduction of evidence of other crimes, wrongs, or acts when relevant to proving "motive, opportunity, intent, preparation, plan, knowledge, identity, or absence of mistake or accident." ${ }^{27}$ The state argued that the pornographic materials showed a "plan" or "grooming" to commit certain sexual acts. ${ }^{28}$ Remy, however, maintained that the material was improper propensity evidence-evidence of other bad acts introduced only to show bad character and that the defendant acted in conformity therewith. ${ }^{29}$

The court of appeals began its analysis by noting that courts faced with challenges under Rule 404(b) must: (1) decide whether the evidence of other bad acts is admissible for a permissible purpose and not simply to show propensity; and (2) "balance the probative value of the evidence against its prejudicial effect

18. IND. R. EVID. 401.

19. IND. R. EVID. 402.

20. Id.

21. Id.

22. IND. R. EVID. 403.

23. $I d$.

24. 17 N.E.3d 396 (Ind. Ct. App. 2014), trans. denied, 23 N.E.3d 17 (Ind. 2015).

25. Id. at 398 .

26. Id. at 399.

27. IND. R. EvID. 404(b).

28. Remy, 17 N.E.3d at 399.

29. Id. 
pursuant to Rule 403." ${ }^{30}$ As to the first point, the court explained that when Indiana adopted Rule 404(b), it intended to narrow the exceptions permitting the introduction of character evidence. ${ }^{31}$ For example, with the adoption of Rule 404(b), Indiana abolished the "depraved sexual instinct" exception to the general bar against character propensity evidence - an exception that permitted character evidence in sexual assault cases to be used to bolster victim credibility and prove that the defendant had acted in conformity with past sexual practices. ${ }^{32}$ This backdrop, the court noted, required care in ensuring that Rule 404(b)'s exceptions do not swallow the rule - a risk it suggested the instant case presented when rationales like "plan" and "grooming" are used to admit prejudicial evidence in child molestation cases. ${ }^{33}$

As to the "plan" rationale, the court analyzed the relevance of the admitted pornographic materials and concluded that few of them really depicted sexual acts that were similar in nature to those the defendant had engaged in with his victim. ${ }^{34}$ The other materials, the court stated, were at most marginally relevant and likely admitted for "no perceivable reason other than to inflame the jury and encourage "forbidden interference." 35 Regarding the "grooming" rationale, the court noted that it has been defined as "the process of cultivating trust with a victim and gradually introducing sexual behaviors until reaching the point where it is possible to perpetrate a sex crime against the victim." ${ }^{36}$ In the case before it, the court stated that on the one hand, the record was not clear as to precisely when the images were shown to the victim, thus making it difficult to conclude that they were particularly relevant to the "grooming" rationale. ${ }^{37}$ On the other hand, admitting the images carried a great risk of unfair prejudice in that the images were overtly sexual and, indeed, may even suggest that the defendant engaged in uncharged criminal conduct. ${ }^{38}$

Overall, based on its assessment of relevance of the materials and its 403 analysis, the court of appeals concluded that the trial court erred in admitting the vast majority of the pornographic images because the danger of unfair prejudice from their admission substantially outweighed their probative value. ${ }^{39}$ Nevertheless, the court found the error was harmless because there was substantial independent evidence demonstrating the defendant's guilt. ${ }^{40}$

30. Id.

31. Id.

32. Id.

33. Id. at 400 .

34. Id.

35. Id.

36. Id. (quoting Piercefield v. State, 877 N.E.2d 1213, 1216 (Ind. Ct. App. 2007), trans. denied, 891 N.E.2d 34 (2008)).

37. Id. at 401 .

38. Id. at 400-01.

39. Id. at 401 .

40. Id. 


\section{B. Evidence of Character, Crimes, and Other Bad Acts (Rule 404)}

As mentioned above, Rule 404(b) permits the introduction of other bad acts evidence for purposes other than to prove propensity to commit the charged crime - for example, to prove motive, opportunity, intent, preparation, plan, knowledge, identity, or absence of mistake. ${ }^{41}$ In Thompson v. State, the Indiana Court of Appeals specifically addressed the defendant's claim that the trial court abused its discretion in permitting the state to introduce evidence that the defendant was a suspect in a different sexual assault case in order to show "identity and modus operandi." ${ }^{42}$ First, the court explained that the Rule 404(b) exception for identity was "crafted primarily for crimes so nearly identical that the modus operandi is virtually a "signature." 43 Further, the court noted that in Lafayette v. State, the Indiana Supreme Court "found that evidence of prior bad acts was not admissible for the purposes of showing identity or modus operandi when the defendant had admitted he had engaged in sexual intercourse with the victim." ${ }^{44}$ Here, defendant Thompson had admitted that he had engaged in sexual intercourse with the victim: his defense was that the victim had consented to the act. ${ }^{45}$ Thus, following Lafayette, the Thompson court concluded that identity was not an issue in the case, and accordingly, evidence of prior bad acts was not admissible for that reason. ${ }^{46}$

The Thompson court also rejected the state's argument that the evidence was nevertheless admissible under Rule 404(b) to show "intent." 7 That exception, the court explained, is only available when a defendant does more than deny the charged culpability and instead alleges a particular contrary intent when presenting his case or cross-examining witnesses ${ }^{48}$ In such cases, the state may respond with other crimes evidence to the extent "genuinely relevant to prove the defendant's intent at the time of the charged offenses." 49 Here, again, the court referenced the Lafayette case wherein the Indiana Supreme Court stated that "a defendant's assertions that an alleged rape victim consented to sexual intercourse does not present a claim of particular contrary intent" for the purposes of applying Rule 404(b). ${ }^{50}$ Instead, as the Lafayette court explained, the issue is whether the victim actually consented. ${ }^{51}$ Here, the court of appeals concluded that the issue in the Thompson case was also whether the victim consented, making inapplicable the intent rationale for the purposes of invoking Rule

41. IND. R. EVID. 404.

42. Thompson v. State, 15 N.E.3d 1097, 1101-03 (Ind. Ct. App. 2014), reh'g denied.

43. Id. at 1102 (quoting Thompson v. State, 609 N.E.2d 224, 234 (Ind. 1997)).

44. Id.

45. Id.

46. Id.

47. Id.

48. Id.

49. Id.

50. Id. (quoting Lafayette v. State, 917 N.E.2d 660, 666 (Ind. 2009)).

51. Id. at 1102-03. 
404(b). ${ }^{52}$ The court reversed the defendant's convictions and remanded for a new trial having decided that admitting the other bad acts evidence was not harmless error. ${ }^{53}$

Whether the trial court properly invoked Rule 404(b) to permit a detective to testify that the reason he arrived at the defendant's house was because the defendant was a suspect in another case was the issue before the Indiana Supreme Court in Inman v. State. ${ }^{54}$ At trial, the court rejected the defendant's suggestion that the detective only refer to Inman as a "person of interest" and instead permitted the prosecutor to elicit that the detective was present at the house to "apprehend" Inman for an unrelated crime. ${ }^{55}$ At Inman's request, however, the trial court did read the jury a limiting instruction, which, among other things, cautioned jurors not to give the testimony regarding the unrelated crime any weight in determining the verdict in the case before it. ${ }^{56}$ On appeal, the court determined that the trial court had abused its discretion in permitting the detective to testify about the unrelated crime because it "invited the jurors to make the impermissible inference that because Inman was being investigated for another crime, he commits crimes, and because Inman commits crimes," he committed the charged crime..$^{57}$ The court stated that this was precisely the type of evidence that Rule 404(b) prohibited. ${ }^{58}$ It nevertheless found that in the instant case the error was harmless because the limiting instruction warned the jurors not to give any weight to the admitted evidence and because the jurors never learned of the nature of the unrelated crime. ${ }^{59}$

The trial court's decision to admit prior bad acts evidence under Rule 404(b) was also the subject of Baker $v$. State. ${ }^{60}$ The charge in question involved stealing gasoline, and the prior bad acts evidence also concerned instances where the defendant had previously stolen gas. ${ }^{61}$ Because defendant Baker asserted an alibi defense to the charge at trial, the prosecutor argued that the state was entitled to refute that assertion, using the prior thefts of gas to show knowledge, identity, and intent. ${ }^{62}$ The court of appeals considered each potential rationale for admitting the prior bad acts separately and concluded that none provided a basis for admission under Rule 404(b). ${ }^{63}$ Knowledge was not a sufficient basis for admission because Baker did not claim that he was entitled to take the gas;

52. Id. at 1103 .

53. Id.

54. 4 N.E.3d 190, 196 (Ind. 2014).

55. Id.

56. Id. at 196-97.

57. Id. at 197.

58. Id.

59. Id.

60. 997 N.E.2d 67, 70-72 (Ind. Ct. App. 2013).

61. Id. at 70-71.

62. Id. at 71 .

63. Id. at 71-72. 
rather, he claimed that he was not involved in stealing the gas. ${ }^{64}$ As to identity, the court noted that the exception was crafted primarily for "signature" crimes that were committed in such a similar and unique manner that one could conclude the same person committed them. ${ }^{65}$ In the instant case, however, the court found that the trial record contained no details about the previous instances where the defendant had stolen gas. ${ }^{66}$ Thus, there was no basis for comparing the prior crimes to the charged crimes so as to demonstrate identity. ${ }^{67}$ Finally, intent is an available exception only where the defendant goes beyond merely denying culpability and instead presents a claim of contrary intent. ${ }^{68}$ Here, Baker merely argued that he did not commit the theft. ${ }^{69}$ Although the court of appeals concluded that the trial court erred, it nevertheless found the error harmless in light of the other substantial evidence supporting the jury's guilty verdict. ${ }^{70}$

Finally, in State v. Bennett, the Indiana Court of Appeals analyzed whether evidence of text messages showing conversations between the defendant and an informant about the defendant's sale of cocaine to the informant were properly admitted under Rule 404(b). ${ }^{71}$ First, the court emphasized that Rule 404(b) only permitted the introduction of other crimes evidence in limited circumstances and did not allow the state to introduce other uncharged misconduct so as to punish a person for his general character. ${ }^{72}$ At the same time, the court explained that Rule 404(b) does not bar evidence of uncharged misconduct that is "intrinsic" to the charged offense. ${ }^{73}$ Other uncharged misconduct is "intrinsic" if it occurred at the same time and under the same circumstances as the misconduct that is the subject of the criminal charge. ${ }^{74}$ Moreover, the court stated that evidence of acts done that complete the story of the charged crime is admissible even if it also tends to show that the defendant committed crimes other than those being prosecuted. ${ }^{75}$ Based on this analysis, the court concluded that the referenced text messages were intrinsic to the charged crimes because the activities depicted in the messaging "occur[ed] very near in time and place and under the same circumstances as the crimes charged and complete[] the story of the crime." Indeed, the court referenced one particular text that depicted a conversation

\section{Id. at 71 .}

65. Id. (quoting Thompson v. State, 690 N.E.2d 224, 234 (Ind. 1997)).

66. Id.

67. Id. at $71-72$.

68. Id. at 72 .

69. Id.

70. Id. at 73 .

71. State v. Bennett, 5 N.E.3d 498, 508 (Ind. Ct. App.), trans. denied, 16 N.E.3d 980 (Ind. 2014).

72. Id. at 508-09.

73. Id. at 509 .

74. Id. (quoting Holden v. State, 815 N.E.2d 1049, 1054 (Ind. Ct. App. 2004), trans. denied, 831 N.E.2d 733 (Ind. 2005)).

75. $I d$.

76. $I d$. at 510 (alteration in original). 
between the defendant and a purchaser of cocaine that occurred only a couple of hours before the purchaser admitted he had bought cocaine from the defendant. ${ }^{77}$ Thus, the texts were properly introduced under Rule 404(b) ${ }^{78}$

\section{Witness TESTiMOny (RULES 601-617)}

Several recent Indiana Court of Appeals cases address witness testimony as it relates to impeachment.

Rule 607 was the subject of the Indiana Court of Appeals' decision in Herron v. State. ${ }^{79}$ There, the court explained that although Rule 607 allows a party to impeach its own witness, a party cannot put a witness on the stand for the sole purpose of introducing evidence cloaked as impeachment that would otherwise be inadmissible at trial. ${ }^{80}$ In assessing whether the government had acted improperly in the case before it, the court noted that courts generally decline to find that a witness was called for the sole purpose of impeachment "where the witness observed the underlying crime and provided, on the stand, other relevant testimony." ${ }^{81}$ Applying this standard, the court of appeals found that the record belied the government's claim that the witness's testimony served a legitimate non-impeachment purpose. ${ }^{82}$ First, the witness did not observe the crime. ${ }^{83}$ Second, the court rejected the state's suggestion that it needed the witness's testimony to corroborate an officer's testimony that he had spoken to the witness and received some information necessary for a search warrant. ${ }^{84}$ The court stated that such evidence was "course-of investigation" evidence that is generally considered irrelevant in that it does not make it more or less probable that the defendant committed the alleged crime. ${ }^{85}$

In Hall v. State, the Indiana Court of Appeals analyzed the question of what constitutes a community for the purposes of using reputation evidence to impeach. ${ }^{86}$ Specifically, the defendant challenged the trial court's decision to disallow proffered testimony under Rule 608(b) about a witness's reputation for untruthfulness within the witness's family. ${ }^{87}$ Regarding Rule 608(b), the court of appeals agreed with the defendant that it allows a party to attack the credibility of a witness using reputation or opinion testimony as to the witness's character for untruthfulness. ${ }^{88}$ On the question of the relevant "community," the court said

77. Id.

78. Id. at 511.

79. 10 N.E.3d 552, 555 (Ind. Ct. App. 2014).

80. Id. at 556 .

81. Id.

82. Id.

83. Id.

84. Id.

85. Id.

86. Hall v. State, 15 N.E.3d 1107, 1116 (Ind. Ct. App. 2014).

87. Id. at 1116-17.

88. Id. at 1116. 
that it references a "group whose size constitutes an indicium of inherent reliability." 89 A group must be sufficiently large to be considered reliable and also not so insular that the opinion of the witness's reputation for truthfulness would not be formed with a set of common biases. ${ }^{90}$ The court of appeals, however, did not rule out the possibility that a family could constitute a community but only if that family is of sufficient size to provide the required reliability. ${ }^{91}$ Based on these guidelines, and applying an abuse of discretion standard, the court of appeals decided that it could not say the trial court erred in disallowing the impeachment testimony, particularly as there was no evidence presented as to the size of the witness's family. ${ }^{92}$

\title{
V. LAY AND EXPERT WITNESSES (RULES 701-705)
}

The Indiana Rules of Evidence place limits on both lay and expert witness testimony. ${ }^{93}$ Rule 701 provides that lay witnesses may provide "opinion" testimony only if "rationally based on the witness's perception and ... helpful to a clear understanding of the witness's testimony or to a determination of a fact in issue." 94 The court considered the necessary foundation for lay skilled witness opinion testimony in A.J.R. v. State. ${ }^{95}$ There, the trial court had allowed an officer to testify as to the likely direction from which gunshots were fired in a case where a juvenile defendant was charged with shooting two cattle. ${ }^{96}$ The defendant's claim of error concerned testimony to the effect that the officer was a member of a team that handled and was familiar with the type of rifle used in the shooting and that his observation of the shell casing led him to believe that the shots were fired from the driver's side of a westbound-facing vehicle. ${ }^{97}$ The defendant argued that because the officer did not actually witness the rifle being shot, his testimony was not rationally based on his perception. ${ }^{98}$ The court disagreed, first noting that "skilled witnesses," like the officer, may testify under Rule $701 .{ }^{99}$ The court explained that skilled witnesses are those with specialized knowledge short of that necessary to be declared an expert witness. ${ }^{100}$ Further, skilled witnesses may testify not only about their observations but also about "“opinions or inferences that are based solely on facts within their own personal

\author{
89. Id. \\ 90. Id. \\ 91. Id. \\ 92. Id. at $1116-17$. \\ 93. See IND. R. EVID. 701-705. \\ 94. IND. R. EVID. 701. \\ 95. 3 N.E.3d 1000, 1003-04 (Ind. Ct. App. 2014). \\ 96. Id. at 1001 . \\ 97. Id. at 1003 . \\ 98. Id. at 1004 . \\ 99. Id. \\ 100. Id. at 1003 .
}


knowledge." "101 In this case, the proper foundation for the officer's testimony was laid precisely because: (1) the officer testified that he was familiar with the type of rifle and ammunition used in the shooting and how shell casings are ejected; and (2) he personally observed the locations of the shell casings on the road. ${ }^{102}$ Accordingly, the officer could give his opinion regarding the likely location from which the shots were fired. ${ }^{103}$

The Rules place additional limits on expert testimony. ${ }^{104}$ First, experts must be qualified to testify based on knowledge, skill, training, or education. ${ }^{105}$ Further, they may only testify to the extent that their testimony will "help the trier of fact to understand the evidence or to determine a fact in issue."106 Experts, however, can base their testimony and opinions even on inadmissible evidence as long as others in the same field reasonably rely on such evidence. ${ }^{107}$ For scientific expert testimony to be admissible, the trial court must first satisfy itself that the testimony is grounded in "reliable scientific principles." 108

Whether two detectives were properly qualified to testify as experts regarding the presence of marijuana on the defendant's person was the subject of the court of appeals' decision in Clark v. State. ${ }^{109}$ The court began its analysis of the issue by pointing out that a trial court has discretion to determine whether a witness is qualified to testify as an expert and that such expertise may be demonstrated by practical experience, not only by formal training. ${ }^{110}$ On the facts before it, the court of appeals concluded that the witnesses were sufficiently qualified as experts to testify about the presence of marijuana. ${ }^{111}$ The court pointed out that both detectives testified that they had been police officers for between seven and thirteen years and while in those positions had not only observed and smelled marijuana, but had also taken numerous classes on drug recognition. ${ }^{112}$

On the other hand, the court of appeals agreed that the trial court had properly refused to qualify a witness as an expert under Rule 702 in Estate of Borgwald v. Old National Bank. ${ }^{113}$ In that case, the issue was whether a decedent possessed the necessary mental capacity to enter into a contract. ${ }^{114}$ Based on the

101. Id. (quoting Hawkins v. State, 884 N.E.2d 939, 944 (Ind. Ct. App.), trans. denied, 898

N.E.2d 1215 (Ind. 2008)).

102. Id. at 1004 .

103. Id.

104. See IND. R. EVID. 702-703.

105. IND. R. EVID. 702(a).

106. Id.

107. IND. R. EVID. 703.

108. IND. R. EVID. 702(b).

109. 6 N.E.3d 992, 997 (Ind. Ct. App. 2014).

110. Id. at 998 .

111. Id. at 998-99.

112. Id.

113. 12 N.E.3d 252, 258 (Ind. Ct. App. 2014).

114. Id. at 255-56. 
evidence, the court of appeals decided that the proffered expert was not one with sufficient skill or knowledge to assist the trier of fact in assessing the witness's mental capacity at the relevant time. ${ }^{115}$ The witness was an ob/gyn, but the court noted that experts in one field cannot offer expert opinions in other fields without a showing of competency in that other field. ${ }^{116}$ Here, no such competency was shown. ${ }^{117}$ Rather, the witness had never met or treated the decedent, and he formulated an opinion about mental competency solely based on a review of reports issued by the decedent's treating psychiatrist and internist. ${ }^{118}$ Given that the witness had no independent competency in recognizing neurological disease or diagnosing age-related mental deficiencies, the court decided his conclusions would be of no assistance to the trier of fact. ${ }^{119}$

The type of evidence experts may rely on was an issue for the Indiana Supreme Court in Knapp v. State. ${ }^{120}$ Specifically, the defendant argued the trial court erred by allowing an expert to base his opinion on photographs that were allegedly unreliable because of uncertainty about when they were taken. ${ }^{121}$ The photos in question were those detailing the crime scene and were introduced through the testimony of a doctor who had performed an autopsy on the victim. ${ }^{122}$ The court rejected the defendant's argument. ${ }^{123}$ It stated that Rule 703 permits experts to rely on evidence of a type reasonably relied upon in their field even if that evidence is otherwise inadmissible. ${ }^{124}$ Thus, in this case it "was surely reasonable for Dr. Kohr to rely on the photos' date and time as accurate enough for the assessment he had been asked to make" given that the photos themselves had encoding to show they were taken during a three-hour time period on August $20 .{ }^{125}$

The Indiana Court of Appeals similarly concluded that an expert's reliance on particular materials in formulating his opinions was proper in Duneland Properties, LLC v. Northern Indiana Public Service Co ${ }^{126}$ There, the defendant objected to an expert engineer's estimate as to the costs of relocating certain power lines onto a new easement stating that the expert had improperly relied on material and labor estimates from others in formulating his own estimate. ${ }^{127} \mathrm{In}$ short, the defendant argued that the expert had based his own opinion on cost estimates that constituted hearsay and about which the expert had no personal

115. Id. at 261 .

116. Id. at 257-58.

117. Id. at 258 .

118. Id.

119. Id.

120. 9 N.E.3d 1274, 1282-83 (Ind. 2014), cert. denied, 2015 WL 133288 (2015).

121. $I d$.

122. Id. at $1281-82$.

123. Id. at 1283 .

124. Id.

125. Id. at $1282-83$.

126. 14 N.E.3d 95, 104 (Ind. Ct. App. 2014).

127. Id. at 103 . 
knowledge, as he was qualified as an expert engineer, not an expert accountant. ${ }^{128}$ For example, on cross-examination, the expert admitted that he did not have personal knowledge of the cost of a pole. ${ }^{129}$ Instead, the expert stated that he uses a computer software package that "automatically retrieves the material costs from [a] purchasing system," and the software package then applies a labor index to the labor multiplier that is attached to each type of material. ${ }^{130}$ This reliance, the court of appeals stated, was proper on the facts presented in the case before it. ${ }^{131}$ The court explained that Rule 703 "is based on the assumption that truly qualified experts are capable of evaluating the information of a sort normally relied on by others in their field." 132 The court cautioned that the rule does not permit experts to merely repeat opinions of others: "[T]he expert must bring his own expertise to bear in reaching his opinion and may not simply repeat opinions of others." explaining that some experts customarily gather information from others and rely upon it to reach their own conclusions. ${ }^{134}$ Here, because the expert had been using the software system for years as part of his engineering job and relying on it to complete material and labor estimates used to build power lines, the court of appeals said that reliance was proper under Rule $703 .{ }^{135}$

In Barnhart v. State, the Indiana Court of Appeals addressed the standards for establishing the reliability of scientific evidence under Rule 702(b) ${ }^{136}$ In that case, the defendant argued that the trial court abused its discretion in excluding scientific evidence of the victim's test results from a drug screen. ${ }^{137}$ The defendant argued that the evidence of a negative screen was relevant to attack the victim's credibility as a witness since she had testified that the defendant had given her marijuana the day before he had sexually abused her. ${ }^{138}$ Though the court of appeals explained that there is no specific test that must be satisfied to satisfy Rule 702(b), it also explained that a trial court may only admit expert scientific testimony if the court is satisfied that it is reliable. ${ }^{139}$ Relevant factors to make the reliability finding include: (1) whether the technique can be tested empirically; (2) whether it has been subjected to peer review; (3) the technique's rate of error or standards to control the operation of the technique; and (4) the technique's general acceptance in the scientific community. ${ }^{140}$ Given the facts

128. Id. at $102-03$.

129. Id. at 103-04.

130. Id. at 103 .

131. Id. at 104 .

132. $I d$.

133. Id. at 105 .

134. Id.

135. Id.

136. Barnhart v. State, 15 N.E.3d 138, 144 (Ind. Ct. App. 2014).

137. Id. at 141 .

138. Id. at $140,144$.

139. Id. at 144 .

140. Id. 
in this case, the court of appeals concluded that the trial court did not err in refusing to permit the witness to testify about the urinalysis results. ${ }^{141}$ Indeed, the witness who took custody of the urine sample did not test it herself and was not able to testify as to the precise tests performed on the sample or any specifics regarding the reliability of those tests - such as known error rates or any peer review of the methods. ${ }^{142}$

The rules regarding witness testimony also prohibit both lay opinion witnesses and expert witnesses from testifying " to opinions concerning intent, guilt, or innocence in a criminal case; the truth or falsity of allegations; whether a witness has testified truthfully; or legal conclusions." 143 The reason for these limitations is so that witnesses do not invade the jury's province in determining the weight to give a particular witness's testimony. ${ }^{144}$ In Bean v. State, the Indiana Court of Appeals addressed these limitations on opinion testimony in a child molestation case where the defendant argued that the victim's mother and the child service's investigator had improperly "vouched" for the child victim during their testimony in violation of Rule 704(b). ${ }^{145}$ The court of appeals found that the mother's testimony violated Rule 704(b) because she stated that after speaking with the child, she and her boyfriend believed that the defendant had molested the child. ${ }^{146}$

As to the investigator, his testimony involved explaining how he substantiates allegations of child molestation, including that in the present case, after interviewing the child, he "drew the conclusion to substantiate the allegation.""147 The court of appeals began its analysis regarding the investigator's testimony by noting that it has previously held that "testimony that a claim has been substantiated constitutes an opinion regarding the truth of the allegations, thereby violating" Rule 704(b). ${ }^{148}$ For example, in Bradford $v$. State ${ }^{149}$ the court of appeals found Rule 704(b) was violated where a caseworker testified she had interviewed the victim and other people and thereafter substantiated sexual abuse. ${ }^{150}$ On the other hand, the court of appeals found no violation of Rule 704(b) in Heinzman v. State ${ }^{151}$ where a caseworker's testimony did not specifically refer to the victim or others. ${ }^{152}$ In Heinzman, the caseworker

141. Id. at 145 .

142. Id. at $144-45$.

143. Bean v. State, 15 N.E.3d 12, 18 (Ind. Ct. App.), trans. denied, 18 N.E.3d 1005 (Ind. 2014) (quoting IND. R. EVID. 704(b)).

144. Id.

145. $I d$.

146. $I d$.

147. Id. at 19.

148. Id.

149. 960 N.E.2d 871 (Ind. Ct. App. 2012).

150. Bean, 15 N.E.3d at 19-20 (citing Bradford, 960 N.E.2d at 876-77).

151. 970 N.E.2d 214 (Ind. Ct. App.), trans. granted, vacated in part, summarily aff'd in part, 979 N.E.2d 143 (Ind. 2012).

152. Bean, 15 N.E.3d at 19 (citing Heinzman, 970 N.E.2d at 222). 
testified that the word "“substantiated" simply meant that the allegations had a foundation upon which to proceed with further investigation, whereas an unsubstantiated report meant that there was no basis for further investigation." 153 Concluding that the case before it was more like Bradford, the court found a violation of Rule 704(b). ${ }^{154}$ The investigator vouched for the child victim because he said that he substantiated the allegations against the defendant, thus sending the message to the jury that the investigator believed the child's allegations. ${ }^{155}$ Finally, the court held that the investigator's testimony further violated Rule 704(b) because he stated that the child victim's allegations were "based in reality," words that constitute testimony about truthfulness since they concern exaggeration or fantasy. ${ }^{156}$

The application of Rule 704(b) was also the subject of the court of appeals' decision in Robey v. State. ${ }^{157}$ Here, too, the case concerned child molestation, and the defendant challenged certain testimony that allegedly amounted to improper vouching for the child victim in violation of Rule $704(\mathrm{~b}) .{ }^{158}$ The defendant first challenged testimony of a child services interviewer who stated that the child's demeanor was "matter of fact."159 The court of appeals stated that as to this testimony, its decision in Kindred $v$. State controlled. ${ }^{160}$ In that case, the court "held that an expert may provide general testimony about the signs of coaching in a child victim and can also testify about whether any of the signs were observed in the particular alleged victim." ${ }^{161}$ Here, because the interviewer only provided general testimony that the child victim had a "matter of fact" demeanor, the testimony did not constitute improper vouching testimony. ${ }^{162}$ Moreover, the court held that even if the testimony was improper vouching, the defendant invited the testimony when he argued that a video recording of the child's interview indicated she must be lying because she did not act traumatized. ${ }^{163}$

As to the testimony of the child victim's counselor, the Indiana Court of Appeals agreed with the State that two of the challenged statements could only constitute invited error. ${ }^{164}$ In short, while the counselor stated that she never thought the child was lying to her and that she treated the child assuming she was molested based on what the child said, those statements were elicited in response

153. Id. at 19-20 (quoting Heinzman, 970 N.E.2d at 222).

154. Id. at 20 .

155. Id.

156. Id.

157. 7 N.E.3d 371, 379 (Ind. Ct. App.), trans. denied, 11 N.E.3d 923 (Ind. 2014).

158. Id.

159. $I d$.

160. Id. at 379-80 (citing Kindred v. State, 973 N.E.2d 1245 (Ind. Ct. App. 2012), trans. denied, 982 N.E.2d 298 (Ind. 2013)).

161. Id. at 380 (citing Kindred, 973 N.E.2d at 1257).

162. Id.

163. Id.

164. Id. 
to questioning by defense counsel on cross-examination. ${ }^{165}$ However, the court found error as to a third statement during redirect to the effect that the victim's medical symptoms were caused by the "trauma of the things that she details that the defendant did to her.""166 The court of appeals said this statement constituted impermissible vouching because it showed that the counselor was treating the victim based on what the defendant did to her, which thereby created the "unescapable implication" that the counselor believed the victim. ${ }^{167}$ Because this statement was merely cumulative of the previous statements the defendant himself had elicited, however, the court concluded the error was harmless. ${ }^{168}$

\section{HeARSAY (RULES 801-806)}

Hearsay is a statement "not made by the declarant while testifying at the trial or hearing" and "offered in evidence to prove the truth of the matter asserted."169 Hearsay is typically not admissible evidence at trial unless the evidence satisfies one of the rules establishing an exception to this general rule. ${ }^{170}$

\section{A. Rule 801-Hearsay Versus Nonhearsay}

There is no need to seek to apply an exception to the rule against admitting hearsay unless the challenged evidence satisfies the definition of hearsay. ${ }^{171} \mathrm{In}$ Vaughn v. State, the defendant argued that his Sixth Amendment Confrontation Clause rights were violated when the trial court admitted into evidence videos and photographs of controlled buys between himself and a confidential informant. ${ }^{172}$ The defendant claimed that the videos and photographs were highly prejudicial hearsay and that because the informant did not testify at trial, the defendant was denied his right to confront the witnesses against him. ${ }^{173}$ The court of appeals disagreed. ${ }^{174}$ It said that for evidence to constitute hearsay it must be a statement or other nonverbal conduct intended as an assertion. ${ }^{175}$ The videos and photographs were not meant to be an assertion; rather, they merely showed conduct. ${ }^{176}$ Because the evidence did not constitute hearsay, its admission was not barred by the Confrontation Clause. ${ }^{177}$

165. Id. at $380-81$.

166. Id. at 380 .

167. Id. at 381

168. Id.

169. IND. R. EVID. 801.

170. IND. R. EVID. 802.

171. See generally Vaughn v. State, 13 N.E.3d 873 (Ind. Ct. App.), trans. denied, 17 N.E.3d 932 (Ind. 2014).

172. Id. at 879 .

173. Id.

174. Id. at 880 .

175. Id.

176. Id.

177. Id. 


\section{B. Rule 801(d)(1)(B)-Prior Consistent Statement}

Under Rule 801(d)(1)(B), a prior out-of-court statement by the declarant is admissible as substantive evidence if the declarant testifies at trial and is subject to cross examination about the statement, where the prior statement is "consistent with the declarant's testimony and is offered to rebut an express or implied charge against the declarant of recent fabrication or improper influence or motive." ${ }^{178}$ In Corbally v. State, the defendant argued that the trial court committed error when it permitted an officer to testify about statements a victim made to him concerning the defendant's sexual assault of her. ${ }^{179}$ The trial court admitted the hearsay statements under Rule 801(d)(1)(B) as prior consistent statements of the victim/witness after defense counsel refused to stipulate to the victim's credibility. ${ }^{180}$ The Indiana Court of Appeals held that the trial court misapplied the law when it permitted the use of Rule 801(d)(1)(B) simply because counsel was unwilling to stipulate to credibility. ${ }^{181}$ The court explained that the cases make clear that there is a difference between challenging credibility and satisfying the rule's requirement of an "express or implied charge of fabricated testimony or improper influence or motive." 182 Neither general attacks of a witness's credibility nor general attacks upon a witness's memory, the court explained, constitute the type of attack necessary to invoke Rule 801(d)(1)(B). ${ }^{183}$ Moreover, in this case, the court's review of the trial testimony did not reveal any other evidence showing that defense counsel had mounted the kind of attack that would permit Rule $801(\mathrm{~d})(1)(\mathrm{B})$ to be invoked. ${ }^{184}$ The questioning did challenge the victim's ability to recall because of alcohol consumption and migraine medication. ${ }^{185}$ The testimony also suggested that the photo line-up wherein the victim identified the defendant was unduly suggestive. ${ }^{186}$ However, the court stated that this amounted merely to a general attack on credibility and ability to identify the defendant and did not "permit the State to 'bolster' [the victim's] testimony by introduction of her prior consistent statements" through the officer's testimony. ${ }^{187}$

\section{Rule $801(d)(1)(C)$-Statement of Prior Identification}

Rule $801(\mathrm{~d})(1)(\mathrm{C})$ provides that a witness's prior statements identifying a

178. Corbally v. State, 5 N.E.3d 463, 468 (Ind. Ct. App. 2014) (quoting Modesitt v. State, 578 N.E.2d 649, 654 (Ind. 1991)).

179. $I d$.

180. $I d$.

181. $I d$.

182. Id. at 469 .

183. Id.

184. Id.

185. Id.

186. Id.

187. Id. 
defendant do not constitute inadmissible hearsay when the "declarant testifies at the trial ... and is subject to cross-examination concerning the statement, and the statement is ... one of identification of a person made shortly after perceiving the person." 188 In Davis v. State, the defendant argued that the trial court abused its discretion when it permitted two different officers to testify that a witness had identified the defendant as one of two persons involved in a beating and robbery. ${ }^{189}$ Specifically, the defendant argued that although the officers testified that the witness made statements to them, there was no evidence that the witness actually saw the defendant commit any acts. ${ }^{190}$ The Indiana Court of Appeals, though, concluded that the prior identification evidence was admitted properly given the "facts most favorable to the verdict." 191 Those facts showed that the witness twice told police officers shortly after the events in question that the defendant was one of two persons who beat and robbed the victim. ${ }^{192}$ Although the witness stated at trial that she did not recall meeting the police or telling them that she saw the defendant commit a robbery and beating, the court held that the Rule 801(d)(1)(C) was nevertheless satisfied because the witness did testify at trial and was subject to cross-examination. ${ }^{193}$ Therefore, the trial court did not err in permitting the officers to testify about the prior identifications and any lack of direct evidence that the witness did not perceive the relevant events went to weight as opposed to admissibility. ${ }^{194}$

\section{Rule 801(d)(2)-Statement of a Party Opponent}

In Vaughn v. State, the Indiana Court of Appeals also addressed Rule $801(d)(2)$ in responding to the defendant's objection to the trial court's decision to admit audio recordings of telephone calls between the confidential informant and the defendant. ${ }^{195}$ The court of appeals rejected the defendant's argument that these calls constituted inadmissible hearsay, explaining that any statements by the defendant on the recording were statements by a party-opponent and therefore admissible pursuant to Rule $801(\mathrm{~d})(2) .{ }^{196}$ As to the statement made by the informant on the recordings, the court of appeals also found no hearsay problem. ${ }^{197}$ Those statements, it said, were not offered for the truth of the matter

188. Davis v. State, 13 N.E.3d 939, 945 (Ind. Ct. App.), trans. denied, 18 N.E.3d 289 (Ind. 2014) (quoting IND. R. EVID. 801(d)(1)(C)).

189. Id. at $944-45$.

190. Id. at 945 .

191. Id.

192. Id.

193. Id.

194. Id.

195. Vaughn v. State, 13 N.E.3d 873, 880 (Ind. Ct. App.), trans. denied, 17 N.E.3d 932 (Ind. 2014).

196. Id.

197. Id. 
asserted. ${ }^{198}$ Instead, the informant's statements were designed to prompt the defendant to speak. ${ }^{199}$ Again, the court of appeals found no Confrontation Clause violation because the evidence did not constitute hearsay. ${ }^{200}$

\section{E. Rule 803(2)—Excited Utterance}

In McQuay v. State, the defendant challenged his conviction following a bench trial, arguing that the trial court abused its discretion in permitting a police officer to testify to a victim's out-of-court statement in violation of his Confrontation Clause rights. ${ }^{201}$ Specifically, the defendant objected to an officer's testimony at trial relating a statement by the battery victim to the effect that the defendant had attacked her. ${ }^{202}$ The Indiana Court of Appeals concluded that the testimony was properly admitted. ${ }^{203}$ The court stated that among the exceptions to the rule against admitting hearsay is a rule permitting evidence that constitutes an "excited utterance" under Rule 803(2). ${ }^{204}$ That rule has three elements that must be shown: (1) a startling event; (2) that the declarant made a statement while under the stress of the excitement from that startling event; and (3) "that the statement relates to the event." 205 Those three elements were met in this case according to the court of appeals. ${ }^{206}$ The startling event was the defendant attacking the victim. ${ }^{207}$ The victim/declarant was under the stress of excitement when she spoke to the officer as evidenced by the fact that she was "'hysterical," "“shaken," and "“crying," among other things. ${ }^{208}$ Finally, the victim's statement identifying the defendant as the attacker was about the startling event. ${ }^{209}$

The Indiana Court of Appeals further concluded that the Confrontation Clause did not bar admitting the victim's statements as an excited utterance through the testimony of the officer. ${ }^{210}$ The court explained that the Confrontation Clause only bars admission of out-of-court testimonial statements. ${ }^{211}$ Here, the court decided the victim's statements to the officer were not testimonial. ${ }^{212}$ Testimonial statements, it emphasized, are:

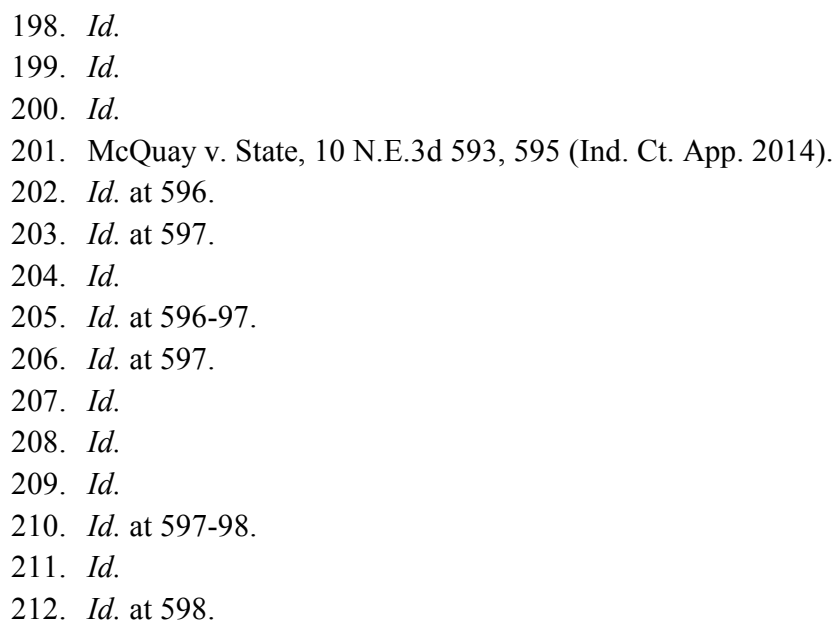


"ex parte in-court testimony or its functional equivalent - that is, material such as affidavits, custodial examinations, prior testimony that the defendant was unable to cross-examine, or similar pretrial statements that declarants would reasonably expect to be used prosecutorially;" "extrajudical statements . . . contained in formalized testimonial materials, such as affidavits, depositions, prior testimony, or confessions;" and "statements that were made under circumstances which would lead an objective witness reasonably to believe that the statement would be available for use at a later trial." ${ }^{, 213}$

Further, the court cited the United States Supreme Court for the proposition that statements are not testimonial "when made in the course of police interrogation under circumstances objectively indicating that the primary purpose of the interrogation is to enable police assistance to meet an ongoing emergency." "214 By contrast, statements are testimonial "“when the circumstances objectively indicate that there is no such ongoing emergency, and that the primary purpose of the interrogation is to establish or prove past events potentially relevant to later criminal prosecution."' 215

On the facts before it, the Indiana Court of Appeals concluded that the statements at issue were not testimonial because the primary purpose of the officer's discussion with the victim "was to enable police assistance to meet an ongoing emergency." 216 The court referenced the following evidence to support its conclusion: (1) the encounter was at the crime scene; (2) the statements were excited utterances, and therefore presumably made before any opportunity to falsify; (3) the statements were made at a time just after the defendant had fled the scene of a violent attack, giving a reasonable officer reason to consider the threat to the public and the victim ongoing; (4) the officer asked the victim's and attacker's identities immediately upon arriving at the scene with no indication that he needed those identifications for the purposes of prosecution; and (5) the discussion was informal and in an exposed, public area. ${ }^{217}$ In sum, the court stated that the facts showed that the officer was obtaining information necessary to help him meet an ongoing emergency since he was responding to a call of a woman being attacked at a time when the public and the victim remained in possible danger given that the defendant had fled the scene. ${ }^{218}$

\section{F. Rule 803(8)-Public Records and Reports}

Public records and reports are admissible under an exception to the rule

213. Id. at 597 (quoting Jackson v. State, 891 N.E.2d 657, 659 (Ind. Ct. App. 2008), abrogated by Koenig v. State, 933 N.E.2d 1271 (Ind. 2010)).

214. Id. at 598 (quoting Davis v. Washington, 547 U.S. 813, 822 (2006)).

215. $I d$.

216. Id.

217. Id. at 598-99.

218. Id. at 599. 
against hearsay if created as part of a regularly conducted activity or investigation. ${ }^{219}$ However, Rule 803(8) does not allow for the introduction of "investigative reports by police or other law enforcement personnel, except when offered by an accused in a criminal case." 220

Averitt Express, Inc. v. Indiana Department of Transportation involved a case where the State sued an Averitt employee whose semi-truck collided with another, thereby damaging the highway and a guardrail. ${ }^{221}$ The State sued Averitt for damages, arguing that it negligently damaged the highway and guardrail. ${ }^{222}$ Averitt appealed the trial court's denial of its motion for summary judgment and grant of summary judgment in the State's favor arguing, among other things, that the trial court improperly admitted the crash report of a trooper who responded to the scene of the collision. ${ }^{223}$ Although the parties agreed that the report contained witness statements that were hearsay, the State argued the report was admissible under Rule $803(8)$ as a public record. ${ }^{224}$ The court of appeals disagreed, stating that Rule 803(8) specifically excludes a police investigative report like that of the trooper's unless offered by an accused in a criminal case. ${ }^{225}$ Because the report was offered by the plaintiff in a civil case, Rule 803(8) was not applicable to authorize the admission of otherwise inadmissible hearsay evidence. ${ }^{226}$ Nor was the court of appeals persuaded that the holding in Fowler v. State ${ }^{227}$ provided an avenue for Indiana to admit the report. ${ }^{228}$ That case held that a police booking report was admissible in a civil case because it was prepared as part of a "'ministerial, nonevaluative booking process." 229 The report here was not routine, the court of appeals stated, because it "was generated during an investigation into an accident resulting in a fatality and property damage." $" 230$

In Vaughn v. State, however, the court of appeals found that Rule 803(8) did not bar the admission of a so-called "police investigative record" that had been offered into evidence by the State against the defendant in a criminal case. ${ }^{231}$ The report in question was a police chain of custody report showing that the cocaine purchased from the defendant during a controlled buy was in the police

219. IND. R. EVID. 803(8).

220. Id.

221. Averitt Express, Inc. v. Ind. Dep’t of Transp., 18 N.E.3d 608, 610-11 (Ind. Ct. App. 2014).

222. $I d$.

223. Id. at 611 .

224. Id. at 611-612.

225. Id. at 612 .

226. Id.

227. 929 N.E.2d 875, 879 (Ind. Ct. App.), trans. denied, 940 N.E.2d 825 (Ind. 2010).

228. Averitt Express, 18 N.E.3d at 612.

229. Id. (quoting Fowler, 929 N.E.2d at 879).

230. $I d$.

231. Vaughn v. State, 13 N.E.3d 873, 882 (Ind. Ct. App.), trans. denied, 17 N.E.3d 932 (Ind. 2014). 
department property locker on one day and moved to the "drug room" on the next. ${ }^{232}$ The defendant argued that the report was not admissible under the public records exception to the hearsay rule because police investigative reports are only admissible by the defense. ${ }^{233}$ The court of appeals disagreed with the defendant's characterization of the report. ${ }^{234}$ It explained that Rule 803(8) applies only to documents that contain factual findings, and moreover, that the "factual findings required to qualify as a public record must address a materially contested issue in the case," to constitute an inadmissible police investigative report. ${ }^{235}$ In the case before it, the court stated that the chain of custody report did not "contain any factual findings that address a materially contested issue in the case nor any factual findings at all." 236 Instead, the report was nothing more than a record of the time and location of evidence, which it referred to as a "rock like substance." ${ }^{237}$ Accordingly, Rule 803(8) did not bar the state from introducing the chain of custody report. ${ }^{238}$

Finally, the Indiana Court of Appeals in Gaines v. State considered Rule 803(8) in the context of a return of service. ${ }^{239}$ The defendant argued that his Confrontation Clause rights were violated when the court permitted a return of service relating to a protective order to be introduced in his criminal trial because he was not able to cross-examine the Sheriff's deputy regarding the service. ${ }^{240}$ In rejecting the defendant's argument, the court of appeals stated that "returns of service are admissible under the public records exception of the hearsay rules."241 As to the Confrontation Clause challenge, and as discussed above, the Confrontation Clause only prohibits the introduction of testimonial evidence without a present or prior opportunity to cross-examine the declarant. ${ }^{242}$ Returns of service, the court of appeals explained, are not testimonial because they are created for the "'administration of an entity's affairs and not for the purpose of establishing or proving some fact at trial." ${ }^{243}$ Further, although Indiana courts had not yet addressed a Confrontation Clause challenge in the return of service context, other courts have concluded that a defendant's Sixth Amendment rights are not violated when such documents are admitted into evidence. ${ }^{244}$ Finding these cases instructive, the court concluded that the primary purpose of the return

232. Id. at $881-83$.

233. Id. at 882 .

234. Id.

235. Id.

236. $I d$.

237. $I d$.

238. $I d$.

239. Gaines v. State, 999 N.E.2d 999, 1003 (Ind. Ct. App. 2014).

240. Id.

241. Id. at 1004 .

242. Id. at 1003 .

243. Id. (quoting Pendergrass v. State, 913 N.E.2d 703, 706 (Ind. 2009), cert. denied, 560 U.S. 965 (2010)).

244. Id. at 1004 . 
of service was administrative, in that it was made to ensure that the defendant received notice of the protective order. ${ }^{245}$ As a result, the return was not testimonial, and its admission did not violate the defendant's Confrontation Clause rights. ${ }^{246}$

\section{G. Rule 804-Unavailability}

The Indiana Rules of Evidence contain additional exceptions to the rule against admitting hearsay in certain cases where the declarant is unavailable to testify at trial. One such exception is Rule 804(b)(1)(A) which provides that where a declarant is unavailable to testify at trial, the declarant's former testimony may be offered against a party who had an opportunity to crossexamine the declarant during the course of that prior testimony. ${ }^{247}$

In Davis v. State, the Indiana Court of Appeals examined this rule in the context of the defendant's argument that the trial court erred in admitting the deposition testimony of two witnesses at his criminal trial. ${ }^{248}$ First, the court agreed with the trial court that the witnesses were "unavailable" - a precondition to applying Rule $804(\mathrm{~b})(1)(\mathrm{A}){ }^{249}$ In this case, the witnesses satisfied the definition of unavailability under Rule 804(a)(5) because they were absent from the trial and the state was not able "by process or other reasonable means" to procure their attendance. ${ }^{250}$ Although the defendant claimed that the state had not made the required effort to obtain the attendance of the witnesses since it only served them the day before trial, the court found that the state had made "repeated efforts" throughout the years of proceedings to bring the witnesses to court, "most of which they ignored, avoided, or disobeyed."251 The court elaborated by detailing various instances where the state had served subpoenas to appear before other trial dates which were ignored, as well as the state's attempt to serve bench warrants on the day of the current trial, which again were ignored. ${ }^{252}$ Accordingly, the court concluded that the trial court had not abused its discretion in determining that the witnesses had made themselves unavailable. ${ }^{253}$ Finally, the court concluded that because the defendant had an opportunity to cross-examine the witnesses during their lawful depositions, those depositions were properly admitted under Rule 804(b)(1)(A). ${ }^{254}$

245. $I d$.

246. Id.

247. IND. R. EVID. 804(b)(1)(A).

248. Davis v. State, 13 N.E.3d 939, 945 (Ind. Ct. App.), trans. denied, 18 N.E.3d 289 (Ind. 2014).

249. Id. at 946 .

250. Id. at $945-46$.

251. Id. at 946 .

252. $I d$.

253. $I d$.

254. Id. at $945-46$. 


\section{Authentication of Evidence (Rule 901)}

Rule 901 requires that the proponent of evidence authenticate it by showing that the evidence is what the proponent claims it to be. ${ }^{255}$ One need not prove authenticity absolutely; the proponent needs to "establish only a reasonable probability that the document is what it is claimed to be."256 Once such reasonable probability is demonstrated, any inconclusiveness regarding authenticity goes to the weight to be accorded the evidence, as opposed to its admissibility. ${ }^{257}$

In Pavlovich v. State, the Indiana Court of Appeals was faced with the novel question of whether text or email had been properly authenticated where there was a "complete lack of technological or documentary evidence linking a party with a particular cell phone number or email address." 258 The defendant in Pavlovich was charged with child solicitation, among other crimes. ${ }^{259}$ The defendant argued that the trial court erred in admitting text and email communications between himself and an undercover detective discussing arrangements for the defendant to have sex with an underage girl. ${ }^{260}$ Because neither the phone number from which the texts were sent nor the email account were registered specifically to the defendant, the defendant argued that they could not be sufficiently linked to him so as to be introduced into evidence against him. ${ }^{261}$ Although the court noted that this lack of a link posed a novel situation, it also noted that Rule 901(b)(4) permits authentication by circumstantial evidence. ${ }^{262}$ The version of Rule 901(b)(4) applicable at the time of Pavlovich's trial allowed evidence to be authenticated by "“[a]ppearance, contents, substance, internal patterns, or other distinctive characteristics, taken in conjunction with circumstances." "263 This type of circumstantial evidence, the court said, was what other courts facing similar issues had found sufficient to authenticate email and text messages. ${ }^{264}$ Here, too, the court of appeals found that there was sufficient circumstantial evidence to authenticate the text and email messages and link them to the defendant. ${ }^{265}$ Specifically, witness testimony showed that meetings with the defendant were arranged by text and

\footnotetext{
255. Pavlovich v. State, 6 N.E.3d 969, 976 (Ind. Ct. App.), trans. denied, 9 N.E.3d 678 (Ind. 2014).

256. Id.

257. $I d$.

258. $I d$.

259. Id. at 973-74.

260. Id. at 974,978 .

261. Id. at 976 .

262. Id.

263. Id. (quoting IND. R. EVID. 901(b)(4)). Rule 901 was amended as of January 14, 2014, but the substance of section (b)(4) was not altered in any material way.

264. Id. at 976-77.

265. Id. at 978 .
} 
email, and the messages revealed the sender's familiarity with the victim. ${ }^{266}$ Moreover, the messages advised of the defendant's location, which was the location where the defendant was arrested. ${ }^{267}$ Moreover, after the defendant was arrested, the email and text accounts went silent. ${ }^{268}$ Even if this did not constitute undisputable proof that Pavlovich wrote the messages, the court stated that any lingering doubts went to evidentiary weight, not to admissibility. ${ }^{269}$

\section{CONCLUSION}

This survey shows that the Indiana courts are regularly confronted with challenges to the admission of evidence requiring them to consult, interpret, and apply the Indiana Rules of Evidence. By summarizing the more important recent developments in this area of practice, this survey hopes to serve as a useful guide for attorneys, judges, and other interested parties.

266. Id. at $978-79$.

267. Id. at 979 .

268. Id. at $978-79$.

269. Id. at 979 . 